\title{
DUKUNGAN ORGANISASI YANG DIRASAKAN DAN KETERIKATAN KARYAWAN PADA KARYAWAN PT. BANK RAKYAT INDONESIA (Persero) Tbk, CABANG BANDA ACEH
}

\author{
Santi Julita, Iin Andriani \\ Program Studi Psikologi Fakultas Kedokteran, Universitas Syiah Kuala \\ Jl. Tgk Tanoh Abee, Banda Aceh \\ iinandriani1893@yahoo.com
}

\begin{abstract}
Development of globalization impact to a strict competition between the companies. This lead the Human Resources factor into a crucial role in maintaining, directing and developing the company. Therefore, every company needs employees who are bound by their job. One of the things that can encourage the formation of relationship between the employee is perceived organizational support. This study aims to determine the relationship between perceived organizational support by attachment of employees at PT. Bank Rakyat Indonesia (Persero) Tbk, Branch of Banda Aceh. The number of samples in this study were 139 permanent employees who were still working or were not taking time off from work with a minimum term of one year and the last education was diploma. The sampling technique used purposive sampling technique. Collecting the data using the scale adaptation of Survey of Perceived Organizational Support with 17-item version $(\alpha=.91)$ and a scale adaptation of Utrecht Work Engagement Scale (UWES) with 17-item version $(\alpha=.95)$. The results of data analysis using pearson product moment correlation technique that showed a positive relationship between perceived organizational support by attachment of employees at PT. Bank Rakyat Indonesia (Persero) Tbk, Branch of Banda Aceh $\left(\mathrm{r}_{\mathrm{xy}}=.30, \mathrm{p}<.05\right)$. The higher of perceived organizational support to the employee, likewise the higher bound of employee or otherwise.
\end{abstract}

Keywords: perceived organizational support; employee engagement; employees; bank

\begin{abstract}
Abstrak
Perkembangan era globalisasi berdampak pada ketatnya persaingan antar perusahaan. Hal ini menyebabkan faktor Sumber Daya Manusia menjadi sangat krusial sebagai penggerak dalam mempertahankan, mengarahkan dan mengembangkan perusahaan. Oleh karena itu, setiap perusahaan membutuhkan karyawan yang terikat dengan pekerjaanya. Salah satu hal yang mendorong terbentuknya keterikatan karyawan adalah dukungan organisasi yang dirasakan. Penelitian ini bertujuan untuk mengetahui hubungan antara dukungan organisasi yang dirasakan dengan keterikatan karyawan pada karyawan PT. Bank Rakyat Indonesia (Persero) Tbk, Cabang Banda Aceh. Jumlah sampel pada penelitian ini adalah 139 karyawan tetap yang masih aktif bekerja atau sedang tidak mengambil cuti kerja dengan masa kerja minimal 1 tahun dan pendidikan terakhir diploma. Teknik pengambilan sampel menggunakan teknik purposive sampling. Pengumpulan data menggunakan skala adaptasi Survey of Perceived Organizational Support versi 17 aitem $(\alpha=0,91)$ dan skala adaptasi Utrecht Work Engagement Scale (UWES) versi 17 aitem $(\alpha=0,95)$. Hasil analisis data menggunakan teknik korelasi pearson product moment menunjukkan adanya hubungan positif antara dukungan organisasi yang dirasakan dengan keterikatan karyawan pada karyawan PT. Bank Rakyat Indonesia (Persero) Tbk, Cabang Banda Aceh $\left(\mathrm{r}_{\mathrm{xy}}=0,30\right.$ $\mathrm{p}<0,05)$. Semakin tinggi dukungan organisasi yang dirasakan, maka semakin tinggi pula keterikatan karyawan ataupun sebaliknya.
\end{abstract}

Kata kunci: perceived organizational support; employee engagement; karyawan; bank

\section{PENDAHULUAN}

Era globalisasi mengakibatkan munculnya tuntutan baru bagi setiap perusahaan untuk mampu menghadapi dan bersaing dengan perusahaan lain yang berada di dalam maupun di luar negeri (Satwika \& Himan, 2014). Munculnya tuntutan-tuntutan tersebut akan membuat setiap perusahaan terus melakukan berbagai upaya agar dapat bertahan dan menjadi yang terbaik (Widodo \& Sami'an, 2013). Sebuah perusahaan dapat 
bertahan dan menjadi yang terbaik dalam dunia persaingan tentunya tidak luput dari peran sumber daya manusia. Hal ini dikarenakan faktor sumber daya manusia merupakan hal yang sangat krusial sebagai penggerak dalam mempertahankan, mengarahkan dan mengembangkan perusahaan (Hidayati, Purwoto \& Yuwono, 2010). Oleh karena itu, setiap perusahaan membutuhkan karyawan yang memiliki keterikatan dengan pekerjaannya atau sering dikenal dengan istilah employee engagement (Bakker \& Leiter, 2010).

Employee engagement diartikan sebagai suatu keadaan yang positif yang membuat karyawan termotivasi dalam menyelesaikan pekerjaan yang ditandai dengan adanya vigor, dedication dan absorption ketika berhadapan dengan pekerjaan (Schaufeli, Salanova, Gonzalez-Roma dan Bakker, 2002). Kahn (1990) mengatakan ada dua bentuk reaksi keterikatan karyawan dengan pekerjaan, yaitu karyawan yang engagement dan karyawan disengagement. Karyawan yang engaged dicirikan sebagai karyawan yang memiliki rasa antusias, semangat dan bergairah ketika berhubungan dengan pekerjaan, loyal, memiliki motivasi, berkomitmen dan selalu produktif (Santosa, 2012). Sementara karyawan yang disengagement dicirikan sebagai karyawan yang cenderung hanya berkonsentrasi pada tugas-tugas daripada sasaran perusahaan, dengan kata lain karyawan yang disengagement merupakan karyawan yang hanya ingin mengetahui apa saja hal-hal yang harus dikerjakan daripada berfokus pada hasil kerjanya. Selain itu, karyawan yang diengagement akan lebih cenderung memiliki niat untuk keluar dari perusahaan (Santosa, 2012).

Hasil penelitian menunjukkan bahwa perusahaan yang memiliki tingkat employee engagement yang tinggi dapat mengurangi angka turnover dan ketidakhadiran karyawan, mengurangi angka kecelakaan ketika bekerja, meningkatkan kepuasan, meminimalkan keluhan karyawan, dan meningkatkan produktivitas perusahaan (Marciano, 2010). Sedangkan bagi karyawan, employee engagement akan membuat karyawan cenderung memiliki perasaan positif terhadap pekerjaan, sehingga akan memengaruhi aktivitas karyawan ketika bekerja (Schaufeli \& Bakker, 2003). Hal ini dikarenakan engagament merupakan salah satu faktor internal dari dalam diri karyawan yang dapat memengaruhi perilaku produktif dan dapat membantu karyawan dalam pengembangan diri untuk menjadi lebih baik (Widodo \& Sami'an, 2013), sehingga employee engagement merupakan hal yang sangat penting bagi kesuksesan sebuah perusahaan (Zulkarnain \& Hadiyani, 2014).

Meskipun banyak hasil penelitian menunjukkan bahwa employee engagement memberikan dampak positif bagi perusahaan dan karyawan, namun pada kenyataannya masih banyak perusahaan yang memiliki tingkat employee engagement yang rendah. Hasil survey Marketing Research Intelligence (MRI) pada tahun 2012 menunjukkan dua pertiga atau $66 \%$ karyawan di Indonesia (70,13 juta jiwa) tidak memiliki engagement terhadap pekerjaannya. Hal ini dipicu oleh minimnya perhatian dari pihak manajemen perusahaan terhadap pemenuhan kesejahteraan karyawan secara psikologis (Putri, Baga \& Sunarti, 2015). Selain itu, data tersebut turut didukung dengan hasil survey Global Workforce Study (GWS) yang dilakukan pada tahun 2014 juga menunjukkan hasil yang serupa, yaitu sebanyak $66 \%$ karyawan di Indonesia tidak memiliki engagament dan cenderung memiliki keinginan untuk meninggalkan perusahaan dalam jangka waktu dua tahun kedepan (Consultancy, 2014).

Industri perbankan merupakan sebuah lembaga keuangan yang menunjukkan kiprahnya dalam mendukung perekonomian sosial dengan menghimpun dan menyalurkan kembali dana ke masyarakat dalam bentuk kredit, pembayaran dan peredaran uang (Yusrina, 2013). Hal tersebut menyebabkan tingginya tuntutan kerja pada karyawan 
perbankan dan lamanya waktu bekerja yang melebihi jam kerja pada umumnya, yaitu lebih dari 8 jam perharinya (Sitepu, 2013). Selaras dengan pernyataan tersebut, Fitri (2013) dalam penelitiannya juga mengatakan bahwa karyawan perbankan memiliki tingkat aktivitas berpikir lebih tinggi dibandingkan dengan pekerjaan lain, sehingga tidak jarang karyawan perbankan mengalami kelelahan, menurunnya konsentrasi ketika bekerja, stress, depresi dan burnout.

Hasil survey yang dilakukan oleh PricewaterhouseCooper (PwC) Indonesia terhadap industri perbankan di Indonesia menunjukkan tingginya angka turnover karyawan perbankan yang mencapai $15 \%$ (Helen, 2014). Menurut Roseman (dalam Widjaja, Fulbertus \& Kusuma, 2008) jika angka turnover di dalam sebuah perusahaan melebihi angka $10 \%$, maka hal tersebut dapat dikategorikan tinggi. Kemudian, tingginya angka turnover karyawan bank di Indonesia juga diikuti dengan penurunan tingkat kinerja organisasi perbankan di Aceh, terutama pada bank pemerintah (BUMN). Pernyataan tersebut diperoleh dari hasil survey yang dilakukan oleh pihak Bank Indonesia terhadap industri perbankan di Aceh (Kajian Regional Provinsi Aceh, 2015).

PT. Bank Rakyat Indonesia (Persero) Tbk merupakan salah satu bank BUMN tertua yang membukukan laba bersih terbesar di Indonesia (Putri, Baga \& Sunarti, 2015). Oleh karena itu, PT. Bank Rakyat Indonesia (Persero) Tbk memiliki target tinggi yang harus dicapai pada setiap tahunnya. Namun, hal tersebut tidak terealisasikan sebagaimana mestinya. Hal ini terlihat dari ketidakmampuan pihak PT. Bank Rakyat Indonesia (Persero) Tbk, Cabang Krekot Provinsi DKI Jakarta dalam mencapai targettarget yang telah disusun pada setiap tahunnya (Adityawarman, Sanim, \& Sinaga, 2015). Selain itu, PT. Bank Rakyat Indonesia (Persero) Tbk juga merupakan salah satu bank BUMN yang memiliki tingkat turnover yang tinggi, seperti yang terjadi pada PT. Bank Rakyat Indonesia (Persero) Tbk,
Cabang Bogor Dewi Sartika Provinsi Jawa Barat pada tahun 2013 silam yang mencapai 20\% (Putri, Baga \& Sunarti, 2015).

Berdasarkan pemaparan diatas dapat dilihat bahwa ketidakmampuan pihak PT. Bank Rakyat Indonesia (Persero) Tbk dalam mencapai target serta tingginya angka turnover karyawan mengindikasikan adanya tingkat employee engagement yang rendah pada karyawan PT. Bank Rakyat Indonesia (Persero) Tbk. Albrecht (dalam Zulkarnain \& Hadiyani, 2014) mengatakan rendahnya employee engagement juga akan terlihat dari minimnya keinginan karyawan untuk terlibat dengan pekerjaan secara fisik, emosi, dan energi dalam menyelesaikan pekerjaan, seperti rendahnya keinginan karyawan untuk melakukan pengorbanan baik tenaga, pikiran dan waktu dalam menyelesaikan pekerjaan (Schaufeli, Salanova, Gonzales-Roma \& Bakker, 2002). Hal tersebut turut diperkuat dengan hasil wawancara singkat yang dilakukan oleh peneliti dengan dua orang karyawan PT. Bank Rakyat Indonesia (Persero) Tbk, Cabang Banda Aceh yang menunjukkan rendahnya keinginan karyawan untuk terlibat secara fisik, kognitif dan emosi dengan pekerjaan. Hal ini terlihat dari tidak adanya rasa bangga terhadap pekerjaan, adanya perasaan enggan untuk lembur, kurangnya konsentrasi saat bekerja, tidak merasa sulit untuk berpisah dengan pekerjaan serta adanya keinginan untuk keluar dari perusahaan, yang mana kesediaan karyawan dalam menuangkan energi penuh ketika bekerja dan adanya keinginan untuk terus bekerja merupakan beberapa hal yang dapat menggambarkan employee engagement, sehingga akan berpengaruh terhadap kinerja karyawan dan kemudian akan berdampak pada performansi perusahaan (Ramadhan \& Sembiring, 2014).

Saks (2006) mengatakan salah satu variabel yang dapat memengaruhi terbentuknya employee engagement adalah perceived organizational support. Perceived organizational support diartikan sebagai sebuah keyakinan umum yang dibentuk oleh 
karyawan terhadap perusahaan mengenai sejauh mana perusahaan dapat menghargai kontribusi dan peduli akan kesejahteraan mereka (Rhoades \& Eisenberger, 2002). Perusahaan yang memperhatikan dan menghargai kinerja karyawan dengan memberikan reward dalam bentuk kompensasi, promosi dan pengakuan akan membuat karyawan senantiasa menunjukkan perilaku yang dapat membantu dalam pencapaian tujuan perusahaan, dengan kata lain karyawan akan bekerja secara extra effort. Hal sebaliknya akan terjadi jika karyawan merasa bahwa dirinya tidak diperhatikan dan dihargai keberadaannya oleh perusahaan, maka akan menimbulkan rasa ketidaknyamanan pada karyawan, timbulnya ketidakpuasan, dan tidak adanya engagement terhadap perusahaan yang pada akhirnya akan berdampak pada kinerja karyawan (Mujiasih, 2015).

Data di lapangan menunjukkan terjadinya penurunan tingkat kinerja karyawan PT. Bank Rakyat Indonesia (Persero) Tbk, cabang Bireun Provinsi Aceh yang disebabkan oleh sistem pelaksanaan pengembangan karir yang tidak sesuai dengan prosedur dan danya kondisi kerja yang tidak menyenangkan, sehingga hal tersebut menyebabkan rendahnya keinginan karyawan untuk dapat bekerja secara maksimal (Muliana, Hafasuddin \& Ibrahim, 2015). Adanya sistem pelaksanaan pengembangan karir yang terarah akan membuat membuat karyawan termotivasi untuk bekerja, hal ini dikarenakan pemberian kesempatan yang sama kepada setiap karyawan dalam pengembangan karir akan membuat karyawan merasa mendapatkan keadilan dan merasa karirnya diperhatikan oleh perusahaan (Haryani, 2013). Hal serupa juga diungkapkan oleh Paputungan (2013) yang mengatakan pemberian kesempatan kepada karyawan dalam pengembangan karir dapat memengaruhi perceived organizational support dan kemudian akan berdampak pada kinerja karyawan.
Di samping itu, hasil wawancara yang dilakukan oleh peneliti dengan salah seorang karyawan PT. Bank Rakyat Indonesia (Persero) Tbk, Cabang Banda Aceh menunjukkan bahwa subjek tidak merasa bahwa dirinya dihargai dan diperhatikan keberadaannya oleh perusahaan serta rekan kerja yang tidak terlalu peduli dengan lingkungan sekitar, sehingga membuat subjek tidak termotivasi untuk bekerja. Senada dengan pernyataan tersebut, Susmiati dan Sudarma (2015) mengatakan adanya penilaian negatif dari karyawan terhadap perlakuan-perlakuan yang diberikan oleh perusahaan akan berdampak pada rendahnya tingkat perceived organizational support, sehingga mengakibatkan munculnya sikap pasif dari karyawan ketika bekerja, mulai tidak peduli terhadap pekerjaan dan kewajibannya yang kemudian berdampak pada penurunan kinerja karyawan (Muliana, Hafasuddin \& Ibrahim, 2015).

Berdasarkan hal tersebut dapat dikatakan bahwa perceived organizational support merupakan hal yang sangat penting bagi karyawan sebagai bukti bahwa perusahaan menghargai dan peduli akan kesejahteraan karyawan. Hal ini dikarenakan perceived organizational support merupakan salah satu cara yang dapat dilakukan oleh pihak perusahaan dalam meningkatkan employee engagement, sehingga karyawan dapat bekerja secara maksimal demi kesuksesan perusahaan (Kurniasari \& Izzati, 2013). Sejalan dengan pernyataan tersebut, hasil penelitian yang dilakukan oleh Ahmadi, Tavakoli dan Heidary (2014) menunjukkan adanya korelasi antara perceived organizational support dengan employee engagement. Semakin tinggi tingkat perceived organizational support, maka semakin tinggi tingkat employee engagement dan sebaliknya, semakin rendah tingkat perceived organizational support, maka semakin rendah tingkat employee engagement. 
Dengan demikian, maka hipotesis dalam penelitian ini adalah terdapat hubungan yang positif antara perceived organizational support dengan employee engagament. Semakin positif perceived organizational support maka akan semakin tinggi tingkat employee engagement, dan sebaliknya. Semakin negatif perceived organizational support maka akan semakin rendah tingkat employee engagement.

\section{METODE}

Penelitian ini dilakukan pada karyawan PT. Bank Rakyat Indonesia (Persero) Tbk, Cabang Aceh dengan menggunakan pendekatan kuantitatif dengan jenis penelitian korelasi. Teknik pengambilan sampel menggunakan teknik purposive sampling dengan karakteristik sebagai berikut: (a) terdaftar sebagai karyawan PT. Bank Rakyat Indonesia (Persero) Tbk, Cabang Banda Aceh yang masih aktif bekerja atau sedang tidak mengambil cuti kerja, (b) berstatus karyawan tetap, (c) masa kerja minimal 1 tahun, (c) pendidikan terakhir diploma. Selanjutnya, besar sampel penelitian ditentukan dengan menggunakan pedoman tabel Issac dan Michael dengan taraf kesalahan 5\% dan taraf kepercayaan 95\%. Berdasarkan tabel Issac dan Michael, jumlah sampel dalam penelitian ini yang sesuai dengan kriteria sampel penelitian berjumlah 139 karyawan tetap (Sugiyono, 2009).

Variabel perceived organizational support diukur dengan menggunakan skala adaptasi Survey Perceived Organizational Support (SPOS) versi 17 aitem yang dikembangkan oleh Rhoades dan Eisenberger (2002) dengan koefisien korelasi aitem berkisar antara 0,370,68 sehingga aitem-aitem tersebut dapat dikatakan valid. Koefisien reliabilitas Skala Perceived Organizational Support sebesar 0,911 , artinya alat ukur tersebut merupakan alat ukur yang tergolong baik dan reliabel. Sedangkan variabel employee Engagement diukur dengan menggunakan skala adaptasi Utrecht Work Engagement Scale (UWES) versi 17 aitem yang disusun oleh Schaufeli dan Bakker (2003) dengan koefisien korelasi aitem berkisar antara 0,594-0,840, sehingga aitem-aitem tersebut dapat dikatakan valid. Koefisien reliabilitas Skala Employee Engagement sebesar 0,901, artinya alat ukur tersebut merupakan alat ukur yang tergolong baik dan reliabel.

Teknik analisis data penelitian menggunakan teknik korelasi pearson product moment. Sebelum data penelitian dianalisis, peneliti melakukan uji asumsi yang meliputi uji normalitas dan uji liniearitas. Uji normalitas dilakukan untuk mengetahui apakah sebaran data penelitian yang diperoleh oleh peneliti berdistribusi normal, memenuhi atau mendekati normal (Idrus, 2009). Data yang dapat dikatakan berdistribusi secara normal adalah data yang berada pada nilai signifikansi p> 0,05 (Priyatno, 2011). Uji normalitas dalam penelitian ini menggunakan teknik statistik one-sample kolmogrovsmirnov test. Uji linieritas dilakukan untuk untuk mengetahui apakah hubungan antara kedua variabel merupakan hubungan yang memiliki garis lurus atau hubungan linier (Idrus,2009). Dua variabel dapat dikatakan memiliki hubungan yang linier apabila nilai signifikansi $\mathrm{p}<0,05$ (Priyatno, 2011). Uji linieritas pada penelitian ini menggunakan test for linierity. Seluruh perhitungan dalam penelitian ini menggunakan bantuan program SPSS versi 21.0 for windows.

\section{HASIL DAN PEMBAHASAN}

Penelitian dilakukan di PT. Bank Rakyat Indonesia (Persero) Tbk, Cabang Banda Aceh dengan jumlah sampel penelitian sebanyak 139 karyawan tetap. Data demografi sampel penelitian yang diperoleh dari penelitian dapat dilihat pada tabel 1 . Berdasarkan tabel 1 dapat dilihat bahwa subjek pada umumnya berada pada rentang usia 25-44 tahun, yaitu sebanyak 117 $(84,3 \%)$ orang. Selain itu, jika ditinjau berdasarkan jenis kelamin dan status pernikahan, sampel penelitian sebagian besar merupakan laki-laki dengan persentase 
Tabel. 1

Data Demografi Sampel Penelitian

\begin{tabular}{|c|c|c|c|c|c|}
\hline No. & Deskripsi Sampel & Kategori & Jumlah & Persentase & Total \\
\hline \multirow[t]{3}{*}{1.} & Usia & $15-24$ & 5 & 3,6 & $100 \%$ \\
\hline & & $25-44$ & 117 & 84,3 & \\
\hline & & $45-64$ & 17 & 12,1 & \\
\hline \multirow[t]{2}{*}{2.} & Jenis Kelamin & Laki-laki & 89 & 64 & $100 \%$ \\
\hline & & Perempuan & 50 & 36 & \\
\hline \multirow[t]{3}{*}{3.} & Pendidikan & D3 & 34 & 24,5 & $100 \%$ \\
\hline & Terakhir & $\mathrm{S} 1$ & 103 & 74,1 & \\
\hline & & S2 & 2 & 1,4 & \\
\hline \multirow[t]{3}{*}{4.} & Masa Kerja & $1-2$ tahun & 11 & 7,9 & $100 \%$ \\
\hline & & 3-10 tahun & 86 & 61,8 & \\
\hline & & Di atas 10 tahun & 42 & 30,3 & \\
\hline \multirow[t]{2}{*}{5.} & Status Pernikahan & Menikah & 105 & 75,5 & $100 \%$ \\
\hline & & Belum Menikah & 34 & 24,5 & \\
\hline
\end{tabular}

sebanyak $89(64 \%)$ orang dan $105(75,5 \%)$ untuk subjek yang telah menikah.

Berdasarkan tingkat pendidikan terlihat bahwa sebanyak 103 (74,1\%) karyawan merupakan lulusan Strata Satu (S-1) dan sebanyak 56 (40,2\%) karyawan bekerja pada bagian marketing. Ditinjau berdasarkan masa kerja, sampel penelitian didominasi oleh karyawan dengan masa kerja 3-10 tahun, yaitu sebanyak $86(61,8 \%)$ orang dan subjek yang berasal dari Provinsi Aceh sebanyak $127(91,2 \%)$ orang.

Sebelum melakukan uji hipotesis, peneliti melakukan uji asumsi dengan melakukan uji normalitas dan uji linieritas. Hasil uji normalitas yang dilakukan pada 139 karyawan PT. Bank Rakyat Indonesia (Persero) Tbk Cabang Banda Aceh menunjukkan untuk variabel perceived organizational support $(\mathrm{z}=0,763, \mathrm{p}=0,606$; $\mathrm{p}>0,05)$, dan variabel employee engagement $(\mathrm{z}=0,959, \mathrm{p}=0,317 ; \mathrm{p}>0,05)$. Hasil tersebut menunjukkan bahwa kedua variabel memiliki sebaran data penelitian yang normal karena memiliki nilai signifikansi lebih besar dari 0,05 . Hasil uji linieritas yang dilakukan dari 139 sampel penelitian melalui ANOVA test for linearity menunjukkan $\mathrm{F}_{\text {lin }}=15,208$ $(\mathrm{p}=0,000, \quad \mathrm{p}<0,001)$. Hal tersebut menggambarkan bahwa adanya hubungan yang liniear antara variabel perceived organizational support dengan employee engagement.
Teknik analisis data penelitian untuk menguji hipotesis penelitian yaitu dengan menggunakan teknik analisis korelasi pearson product moment dikarenakan kedua data variabel penelitian berdistribusi secara normal dan linier. Adapun alasan penggunaan metode tersebut untuk menganalisis hubungan antara perceived organizational support dengan employee engagement pada karyawan PT. Bank Rakyat Indonesia (Persero) Tbk Cabang Banda Aceh.

Hasil analisis dari korelasi pearson product moment menunjukkan nilai $\mathrm{r}=0,301$ $(\mathrm{p}<0,001)$. Hasil tersebut menunjukkan bahwa hipotesis penelitian yang diajukan oleh peneliti diterima, yakni semakin tinggi tingkat perceived organizational support karyawan maka akan semakin tinggi pula tingkat employee engagement, begitu juga sebaliknya semakin rendah perceived organizational support karyawan maka semakin rendah tingkat employee engagement.

Selain itu, hasil analisis data penelitian juga menunjukkan sumbangan efektif dari kedua variabel yang dilihat dari analisis measures of association. Hasil analisis tersebut menunjukkan nilai $\mathrm{R}$ Square $\left(\mathrm{R}^{2}\right)=0,090$, yang artinya terdapat $9 \%$ pengaruh perceived organizational support terhadap employee engagement, sementara $91 \%$ dipengaruhi oleh faktor-faktor lain. 
Temuan ini sejalan dengan beberapa penelitian terdahulu yang menunjukkan adanya keterkaitan antara employee engagement dengan perceived organizational support, diantaranya penelitian yang dilakukan oleh Man dan Hadi (2013) yang melihat hubungan antara perceived organizational support dengan employee engagement pada 128 guru dari 11 SMA Swasta di Surabaya. Hasil penelitian tersebut menunjukkan bahwa tingginya perceived organizational support akan berdampak pada tingginya employee engagement. Semakin tinggi perceived organizational support yang maka semakin tinggi pula tingkat employee engagement dan begitu juga sebaliknya, semakin rendah perceived organizational support maka semakin rendah pula tingkat employee engagement. Tingginya perceived organizational support yang dirasakan oleh karyawan dapat dikarenakan adanya keyakinan jika perusahaan menghargai kinerja yang telah dilakukan oleh karyawan dan adanya perlakuan yang adil dari perusahaan (Setiawan, 2012).

Hal senada juga ditemukan dalam penelitian yang dilakukan oleh Ahmadi, Tavakoli dan Heidary (2014) yang mengungkapkan bahwa perceived organizational support dengan employee engagement memiliki hubungan yang positif dan signifikan. Lebih lanjut dikatakan bahwa para pemimpin harus mencoba untuk meningkatkan persepsi positif karyawan terhadap dukungan organisasi dengan melibatkan karyawan dalam pekerjaan mereka yang mengarah pada pencapaian positif bagi perusahaan, sehingga karyawan akan lebih berdedikasi terhadap pekerjaannya.

Penelitian lainnya yaitu dilakukan oleh Kurniasari dan Izzati (2013) pada 78 PNS Dinas Kesehatan Provinsi Jawa Timur. Hasil penelitian menunjukkan bahwa perceived organizational support berkaitan dengan employee engagement, dimana tingginya tingkat perceived organizational support akan berdampak pada tingginya tingkat employee engagement. Hal tersebut menunjukkan bahwa perceived organizational support merupakan salah satu hal yang dapat memengaruhi terbentuknya employee engagement.

Hasil analisis data penelitian juga menunjukkan koefisien determinasi $\left(\mathrm{R}^{2}\right)$ sebesar 0,09. Hal ini menunjukkan bahwa perceived organizational support memberikan kontribusi sebesar $9 \%$ terhadap employee engagement, sementara 91\% dipengaruhi oleh faktor-faktor lain, seperti persepsi terhadap beban kerja (Saputri \& Prabowo, 2015) dan psychological capital (Nugroho, Mujiasih \& Prihatsanti, 2013).

Faktor persepsi terhadap beban kerja memiliki andil dalam menciptakan employee engagement. Hal ini dibuktikan dengan hasil penelitian yang dilakukan oleh Saputri dan Prabowo (2015) yang menunjukkan jika persepsi terhadap beban kerja memiliki pengaruh cukup besar terhadap employee engagement, yaitu sebesar 42,3\%. Lebih lanjut dikatakan, karyawan yang memiliki persepsi positif terhadap beban kerja akan dengan mudah membangun ikatan emosional dengan perusahaan, dan sebaliknya karyawan yang memiliki persepsi negatif terhadap beban kerja akan enggan untuk mengikat diri dengan perusahaan. Hal ini menunjukkan bahwa karyawan yang engaged adalah karyawan yang memiliki persepsi positif terhadap beban kerja.

Selain itu, hasil penelitian yang dilakukan oleh Nugroho, Mujiasih dan Prihatsanti (2013) menunjukkan psychological capital memberikan kontribusi terhadap employee engagement sebesar 51,3\%. Psychological capital diartikan sebagai kondisi psikologis yang bersifat positif dari individu yang memiliki karakteristik efikasi diri, optimisme, harapan dan resiliensi (Luthans, Youssef \& Avolio, 2007).

Adanya program-program pengelolaan sumber daya manusia yang telah disusun oleh perusahaan, seperti sistem pengembangan karir yang sesuai, sistem 
remunerasi karyawan, adanya program pelatihan dan sistem pengembangan karyawan berdasarkan kompetensi akan memengaruhi karakteristik dari psychological capital dan kemudian akan berdampak pada peningkatan sumber daya pekerjaan atau sering dikenal dengan istilah job resources (Nugroho, Mujiasih \& Prihatsanti, 2013). Job resources diartikan sebagai aspek fisik, psikologis, sosial dari organisasi yang berfungsi sebagai media dalam mencapai tujuan dari pekerjaan, mengurangi tuntutan dari pekerjaan dan menstimulus pertumbuhan dan perkembangan individu, dimana job resources merupakan salah satu faktor yang dapat memengaruhi employee engagement (Schaufeli \& Bakker, 2004).

Berdasarkan hasil analisis data penelitian menggunakan teknik korelasi pearson product moment dengan bantuan program SPSS versi 21.0 for windows didapatkan bahwa sebanyak $79(56,8 \%)$ karyawan PT. Bank Rakyat Indoneisa (Persero) Tbk, Cabang Banda Aceh berada pada kategori employee engagement rata-rata, 58 (41,7\%) karyawan berada pada kategori employee engagement tinggi, sedangkan sisanya 2 $(1,4 \%)$ karyawan berada pada kategori employee engagement sangat tinggi. Hasil penelitian ini menunjukkan hal yang berbeda dengan fenomena awal yang dipaparkan oleh peneliti, dimana hal ini dapat disebabkan oleh faktor dukungan organisasi yang dirasakan oleh karyawan (Saks, 2006) dan budaya organisasi (Akbar, 2013).

PT. Bank Rakyat Indonesia (Persero) Tbk merupakan salah satu perusahaan yang telah menyusun berbagai macam program untuk mengelola SDM perusahaan. Penyediaan lembaga pendidikan BRI Corporate University merupakan salah satu program yang telah disusun oleh pihak PT. Bank Rakyat Indonesia (Persero) Tbk guna meningkatkan kompetensi karyawan melalui pembelajaran soft skill maupun hard skill dalam mengembangkan bisnis perusahaan (Surahman, 2016). Selain itu, melalui lembaga pendidikan BRI Corporate University diharapkan karyawan dapat meningkatkan pengetahuan, kemampuan, keterampilan dan keahlian dalam menghadapi tantangan pekerjaan, sehingga hal tersebut dapat meningkatkan employee engagement (Nugroho, Mujiasih \& Prihatsanti, 2013). Hal ini menunjukkan bahwa pihak PT. Bank Rakyat Indonesia (Persero) Tbk, Cabang Banda Aceh sangat memperhatikan pekerjaan karyawan dan mengakui keberadaan karyawan didalam perusahaan. Adanya perhatian dari perusahaan terhadap pekerjaan karyawan serta pengakuan yang diberikan kepada karyawan akan membuat karyawan lebih berdedikasi terhadap pekerjaannya, sehingga karyawan akan menciptakan ikatan emosional dengan perusahaan (Man \& Hadi, 2013).

Selain memiliki program-program yang diperuntukkan bagi karyawan, PT. Bank Rakyat Indonesia (Persero), Tbk juga memiliki cara-cara tersendiri dalam menciptakan kenyamanan bagi karyawan untuk tetap menjadi bagian dari perusahaan, salah satunya yaitu dengan menciptakan budaya organisasi yang baik. Budaya organisasi diartikan sebagai nilai, sikap-sikap yang telah diyakini serta kebiasan-kebiasan yang sering dilakukan oleh anggota organisasi, sehingga hal-hal tersebut menjadi perilaku keseharian dari organisasi (Susmiati \& Sudarma, 2015). Budaya organisasi pada PT. Bank Rakyat Indonesia (Persero) Tbk, Cabang Banda Aceh tercermin melalui adanya kegiatan yang dilakukan bersamasama dengan karyawan, seperti sharing antar divisi kerja, olahraga bersama, outbound, doa pagi, pembuatan yel-yel untuk setiap divisi kerja hingga kegiatan gathering untuk karyawan beserta keluarga. Dimana dengan adanya kegiatan-kegiatan tersebut membuat karyawan PT. Bank Rakyat Indonesia (Persero) Tbk, Cabang Banda Aceh merasa bahwa perlakuan baik yang diterima dari organisasi dapat menjadi pemenuh kebutuhan secara psikologis, pengakuan, dan rasa bangga yang dirasakan oleh karyawan untuk 
tetap menjadi bagian dari perusahaan, sehingga karyawan akan cenderung mengikat diri dengan perusahaan (Ariani, 2010).

Pernyataan tersebut turut didukung dengan hasil penelitian yang dilakukan oleh Akbar (2013) yang menunjukkan bahwa budaya organisasi memberikan kontribusi sebesar 33,5\% terhadap employee engagement. Lebih lanjut dikatakan karyawan yang memiliki pemahaman dan kecocokan dengan budaya organisasi tempat dimana karyawan bekerja akan dengan mudah memiliki keterikatan dengan perusahaan, sehingga karyawan akan lebih termotivasi dalam bekerja. Hal ini juga terlihat dari sikap kerja yang ditampilkan oleh karyawan PT. Bank Rakyat Indonesia (Persero) Tbk, Cabang Banda Aceh, dimana karyawan cenderung memiliki keinginan yang tinggi untuk melakukan pengorbanan baik tenaga, pikiran dan waktu dalam menyelesaikan pekerjaan. Adanya keinginan karyawan untuk melakukan pengorbanan baik secara fisik, emosi dan energi dalam menyelesaikan pekerjaan merupakan hal-hal yang menggambarkan employee engagement (Schaufeli, Salanova, Gonzales-Roma \& Bakker, 2002).

Hasil analisis data penelitian menggunakan teknik pearson product moment dengan bantuan program SPSS versi 21.0 for windows ini juga menemukan sebanyak 71 $(51,1 \%)$ karyawan berada pada kategori perceived organizational support sedang. Akan tetapi, karyawan yang berada pada kategori perceived organizational support tinggi jauh lebih banyak dibandingkan dengan karyawan yang berada pada kategori perceived organizational support rendah, yaitu sebanyak $67(48,2 \%)$ karyawan untuk kategori tinggi, sedangkan sisanya $1(0,7 \%)$ karyawan untuk kategori perceived organizational support rendah. Hal ini merupakan salah satu hasil positif dari berbagai upaya yang telah dilakukan oleh pihak PT. Bank Rakyat Indonesia (Persero) Tbk dalam meningkatkan kompetensi karyawan melalui program-program yang disusun untuk menunjang kualitas SDM perusahaan (Hapsari, Hadiyati \& Mujiasih, 2013). Melalui program-program tersebut tentunya dapat menjadi salah satu alasan mengapa karyawan PT. Bank Rakyat Indonesia (Persero) Tbk, Cabang Banda Aceh memiliki perceived organizational support yang positif. Selain itu, hal ini juga dapat dipengaruhi oleh faktor-faktor lain yang dapat memengaruhi perceived organizational support pada karyawan PT. Bank Rakyat Indonesia (Persero) Tbk, Cabang Banda Aceh, seperti imbalan/kompensasi (Putra \& Rahyuda, 2016), tingkat pendidikan dan masa kerja (Rhoades \& Eisenberger, 2002).

Kurniasari dan Izzati (2013) menyatakan perceived organizational support akan sangat memengaruhi perilaku kerja dan kinerja seseorang. Hal ini dikarenakan perceived organizational support merupakan hal yang sangat penting bagi karyawan sebagai bukti bahwa perusahaan menghargai dan peduli akan kesejahteraan karyawan. Karyawan yang merasa bahwa keberadaan dan kinerjanya dihargai oleh perusahaan akan memiliki perceived organizational support yang positif dan kemudian akan berdampak pada employee engagement (Man \& Hadi, 2013). Hasil temuan ini membuktikan bahwa karyawan PT. Bank Rakyat Indonesia (Persero) Tbk, Cabang Banda Aceh memiliki perceived organizational support yang positif. Hal ini juga didukung dengan tingkat kompensasi yang tergolong cukup besar yang diberikan oleh PT. Bank Rakyat Indonesia (Persero) Tbk, kepada karyawankaryawannya. Selaras dengan pernyataan tersebut, Putra dan Rahyuda (2016) mengatakan kompensasi merupakan salah satu hal yang dapat memengaruhi percieved organizational support dan tingkat retensi karyawan dalam sebuah perusahaan.

PT. Bank rakyat Indonesia (Persero) Tbk merupakan salah satu perusahaan dengan tingkat kompensasi yang tergolong cukup besar. Bagi karyawan baru dan belum berpengalaman, PT. Bank Rakyat Indonesia (Persero) Tbk memberikan kompensasi 
berkisar antara Rp. 2,8 juta hingga Rp 3,8 juta, sedangkan untuk karyawan lama yang berposisi sebagai manager PT. Bank Rakyat Indonesia (Persero) Tbk memberikan kompensasi sebesar Rp. 20 juta perbulan, sehingga dengan tingkat kompensasi yang tergolong cukup besar dan sempitnya lapangan kerja yang tersedia di Aceh tidak heran jika karyawan PT. Bank Rakyat Indonesia (Persero) Tbk, Cabang Banda Aceh memiliki perceived organizational support yang positif (Wiyanti, 2013). Hal ini dikarenakan karyawan PT. Bank Rakyat Indonesia (Persero) Tbk, Cabang Banda Aceh merasa bahwa adanya penghargaan yang diterimanya dari perusahaan dalam bentuk kompensasi merupakan salah satu wujud bahwa perusahaan menghargai kontribusi dari karyawan dalam mencapai kesuksesan perusahaan (Eisenberger, Huntington, Hutchson \& Sowa, 1986).

Suseno, Hamid dan Ruhana (2014) mengatakan pendidikan dan masa kerja merupakan dua hal yang dapat membedakan sistem pemberian reward kepada karyawan PT. Bank Rakyat Indonesia (Persero) Tbk, Cabang Banda Aceh selain faktor posisi kerja, dimana karyawan dengan status pendidikan lebih tinggi dan masa kerja yang lebih lama akan mendapatkan reward yang lebih besar dibandingkan dengan karyawan yang memiliki tingkat pendidikan dan masa kerja yang belum terlalu lama. Data demografi sampel penelitian menunjukkan sebanyak $103(74,1 \%)$ karyawan PT. Bank Rakyat Indonesia (Persero) Tbk, Cabang Banda Aceh merupakan lulusan Strata Satu (S-1), 34 (24,5\%) karyawan lulusan Diploma dan $2(1,4 \%)$ karyawan lulusan Strata Dua (S-2). Pohan dan Batubara (2014) mengatakan tingkat pendidikan yang ditempuh oleh karyawan akan menyebabkan perbedaan dalam penilaian terhadap dukungan yang diberikan oleh organisasi. Pernyataan tersebut sejalan dengan hasil penelitian yang dilakukan oleh Rhoades dan Eisenberger (2002) yang menunjukkan adanya hubungan yang signifikan antara tingkat pendidikan dengan perceived organizational support.

Allen dan Meyer (1993) membagi masa kerja karyawan ke dalam 3 kelompok, yang pertama kelompok karyawan dengan masa kerja 1-2 tahun yang menjelaskan bahwa karyawan dengan masa kerja tersebut merupakan karyawan yang baru bekerja di dalam organisasi. Kemudian kelompok kedua merupakan karyawan dengan masa kerja 310 tahun, dimana karyawan dengan masa kerja tersebut merupakan karyawan yang berada pada tingkatan tengah, dan terakhir yaitu kelompok masa kerja di atas 10 tahun. Karyawan dengan masa kerja di atas 10 tahun merupakan karyawan yang telah bekerja dengan masa kerja yang lama. Berdasarkan pembagian masa kerja tersebut, hasil penelitian ini menemukan PT. Bank Rakyat Indonesia (Persero) Tbk, Cabang Banda Aceh pada umumnya didominasi oleh karyawan dengan masa kerja 3-10 tahun, yaitu sebanyak $86 \quad(61,8 \%)$ karyawan, kemudian diikuti oleh masa kerja di atas 10 tahun sebanyak 42 (30,3\%) karyawan, dan masa kerja 1-2 tahun sebanyak $11 \quad(7,9 \%)$ karyawan. Rhoades dan Eisenberger (2002) mengatakan bahwa masa kerja merupakan salah satu hal yang dapat memengaruhi perceived organizational support. Hal ini dapat dikarenakan karyawan PT. Bank Rakyat Indonesia (Persero) Tbk, Cabang Banda Aceh dengan masa kerja yang lebih lama telah memiliki penilaian positif terhadap dukungan-dukungan yang diberikan oleh organisasi kepada karyawan baik secara material dan finansial maupun secara psikologis, sehingga karyawan PT. Bank Rakyat Indonesia (Persero) Tbk, Cabang Banda Aceh memiliki perceived organizational support yang positif.

Hal serupa juga ditemukan pada penelitian yang dilakukan oleh Fatdina (2009) yang menunjukkan bahwa karyawan yang telah bekerja dengan waktu yang lama dalam sebuah perusahaan cenderung memiliki perceived organizational support yang tinggi. Lebih lanjut dikatakan bahwa karyawan dengan masa kerja yang lama 
merupakan individu yang terus melakukan penilaian terhadap dukungan yang diberikan oleh organisasi. Sementara karyawan yang baru bekerja didalam sebuah perusahaan merupakan karyawan yang belum sepenuhnya merasakan dukungan yang diberikan oleh perusahaan kepada karyawan, sehingga karyawan belum memiliki perceived organizational support yang positif terhadap perusahaan (Bergiel, Nguyen, Clenner \& Taylor, 2009). Oleh karena itu, dapat dikatakan bahwa semakin lama karyawan bekerja dalam sebuah perusahaan maka akan semakin tinggi tingkat perceived organizational support yang dimiliki oleh karyawan.

\section{SIMPULAN}

Berdasarkan hasil analisis data penelitian dapat disimpulkan bahwa terdapat hubungan positif antara dukungan organisasi yang dirasakan dengan keterikatan karyawan pada karyawan PT. Bank Rakyat Indonesia (Persero) Tbk, Cabang Banda Aceh $\left(\mathrm{r}_{\mathrm{xy}}=\right.$ $0,30 ; p<0,05)$. Hal ini menunjukkan bahwa semakin tinggi dukungan organisasi yang dirasakan maka semakin tinggi pula keterikatan karyawan yang dimiliki. Sebaliknya, semakin rendah dukungan organisasi yang dirasakan maka semakin rendah pula tingkat keterikatan karyawan yang dimiliki. Dukungan organisasi yang dirasakan memberikan kontribusi yang sangat kecil terhadap keterikatan karyawan pada karyawan PT. Bank Rakyat Indonesia (Persero) Tbk Cabang Banda Aceh, yaitu sebesar $9 \%$.

\section{DAFTAR PUSTAKA}

Adityawarman, Y., Sanim, B., \& Sinaga, B. (2015). Pengaruh beban kerja terhadap kinerja karyawan PT. Bank Rakyat Indonesia (persero) Tbk Cabang Krekot. Jurnal Manajemen dan Organisasi, 6, (1), 34-44.

Ahmadi, S. A. A., Tavakoli, S., \& Heidary, P. P. (2014). Perceived organizational support and employee engagement. International Journal of Information Technology and Management Studies, 1, (1), 54-66.

Akbar, M. R. (2013). Pengaruh budaya organisasi terhadap employee engagement (studi pada karyawan PT. PRIMATEXCO Indonesia di Batang). Journal of Social adn Industrial Psychology, 2, (1), 10-18.

Allen, N. J., \& Meyer, J. P. (1993). Organizational citizenship: evidence of career stage effects? Journal of Business Research, 26, (1), 49-61.

Ariani, D. W. (2010). Pengaruh pemoderasian kesamaan nilai dalam hubungan antara dukungan supervisor dan organisasional persepsian dan komitmen organisasional afektif. Buletin Ekonomi, 8, (1), 1-22.

Bakker, A. B., \& Leiter, M. P. (2010). Work engagement: A handbook of essential theory and research. Hove and New York: Psychology Press

Bergiel, E. B., Nguyen, V. Q., Clenney, B. F., \& Taylor (2009). Management Research News, 32, (3), 205-219.

Consultancy. (2014). Towers: Talent management issues for Indonesian firms. Diakses pada tanggal 20 Juni 2016 melalui situs: http://www.consultancy.uk/news/113 3/towers-talent-management-issuefor-indonesian-firms.

Eisenberger, R., Huntington, R., Hutchson, S., \& Sowa, D. (1986). Perceived organizational support. Journal of Applied Psychology, 71, (3), 500-507.

Fatdina. (2009). Peran dukungan organisasi yang dirasakan karyawan sebagai mediator pengaruh keadilan prosedural terhadap perilaku 
kewarganegaraan

organisasi.

Humanitas, 36, (1), 1-17.

Fitri, A. M. (2013). Analisis faktor-faktor yang berhubungan dengan kejadian stres kerja pada karyawan bank (studi pada karyawan Bank BMT). Jurnal Kesehatan Masyarakat, 1, (2).

Hapsari, S. F., Hadiyati, F. N.R., \& Mujiasih, E. (2013). The relationship between perceived of leader-member interaction quality and organizational citizenship behavior on contract employees of Bank Rakyat Indonesia (BRI) regional office Semarang. Empati, 2, (3), 203-212.

Haryani, P. Y. (2013). Korelasi antara pengembangan karir dengan motivasi kerja dan keinginan untuk pensiun dini. Jurnal Buletin Studi Ekonomi, $18,(2), 183-190$.

Hidayati, R., Purwanto, Y., \& Yuwono, S. (2010). Korelasi kecerdasan emosi dan stress kerja dengan kinerja. Indigenous, Jurnal Ilmiah Berkala Psikologi, 12, (1), 81-87.

Helen, D. (2014). Survei SDM Perbankan: Turnover karyawan 15\%, motif utama cari tunjangan lebih menjanjikan. Diaskes pada tanggal 10 Juni 2016 melalui situs: http://m.bisnis.com/finansial/read/201 40515/9022813/survei-sdmperbankan-turn-over-karyawan-15motif-utamanya-cari-tunjangan-lebihmenjanjikan.

Idrus, M. (2009). Metode penelitian ilmu sosial: pendekatan kualitatif dan kuantitatif. Jakarta: Erlangga.

Kahn, W. A. (1990). Psychological conditions of personal engagement and disengagement at work. Academy of Management Journal, 33, (4), 692-724.
Kajian Ekonomi dan Keuangan Regional Provinsi Aceh. (2015). Perkembangan Perbankan Daerah.

Kurniasari, R., \& Izzati, U. A. (2013). Hubungan persepsi dukungan organisasi dengan employee engagement pegawai negeri sipil dinas kesehatan provinsi Jawa Timur. Character, 02, (01), 1-7.

Luthans, F., Youssef, C., \& Avolio, B. J. (2007). Psychological capital: developing the human competitive edge. New York: Oxford University Press.

Man, G. S., \& Hadi, C. (2013). Hubungan antara perceived organizational support dengan work engagament pada guru SMA swasta di Surabaya. Jurnal Psikologi Industri dan Organisasi, 2, (2), 90-99.

Marciano, P. L. (2010). Carrots and stick dont work: Build a Culture of Employee Engagament with the Principle of RESPECT. USA: McGraw Hill.

Mujiasih, E. (2015). Hubungan antara persepsi dukungan organisasi (perceived Organizational Support) dengan keterikatan karyawan (employee engagement). Jurnal Psikologi Undip, 14, (1), 40-51.

Muliana., Hafasnuddin., \& Ibrahim, D. (2015). Pengaruh budaya organisasi, pengembangan karir dan kepuasan kerja terhadap kinerja karyawan serta dampaknya aapda kinerja Bank BRI Cabang Bireun. Jurnal Manajemen Pasca Sarjana Universitas Syiah Kuala, 4, (2), 202-210.

Nugroho, D. A. S., Mujiasih, E., \& Prihatsanti, U. (2013). Hubungan psychological capital dengan work engagement pada karyawan PT. Bank 
Mega Regional area semarang. Jurnal Psikologi Undip, 12, (2), 192-202.

Paputungan, F. R. (2013). Motivasi, jenjang karir dan disiplin kerja pengaruhnya terhadap kinerja karyawan pada PT. Bank Sulut Cabang Calaca. Jurnal EMBA, 1, (4), 679-688.

Pohan, V. G., \& Batubara, R. R. A. (2014). Hubungan persepsi terhadap program kesehatan dan keselamatan kerja (K3) dengan employee engagement. Psikologia, 9, (1), 9-14.

Priyatno, D. (2011). Buku saku analisis statistik data SPSS. Yogyakarta: MediaKom.

Putra, I. B. G. S., \& Rahyuda, A. G. (2016). Pengaruh kompensasi, lingkungan kerja dan perceived organizational support (POS) terhadap retensi karyawan. E-Jurnal Manajemen Unud, 5, (2), 810-837.

Putri, M. S., Baga, L. M., \& Sunarti, E. (2015). Employee engagament, lingkungan sosial dan kinerja karyawan di PT. Bank Rakyat Indonesia Tbk, Kantor Cabang Bogor Dewi Sartika. Menejemen IKM, 10, (2), 123-130.

Ramadhan, N., \& Sembiring, J. (2014). Pengaruh employee engagement terhadap kinerja karyawan di human capital center PT. Telekomunikasi Indonesia, Tbk. Jurnal Manajemen Indonesia, 14, (2), 47-58.

Rhoades, L., \& Eisenberger, R. (2002). Perceived organizational support: A review literature. Journal of Applied Psychology, 87, (4), 698-714.

Saks, A. M. (2006). Antecedents and cosequences of employee engagament. Journal of Managerial Psychology, 21, (7), 600-619.
Santosa, T. E. C. (2012). Memahami dan mendorong terciptanya employee engagement dalam organisasi. Jurnal Manajemen, 11, (2), 207-214.

Saputri, K. E., \& Prabowo, S. (2015). Employee engagement ditinjau dari persepsi beban kerja. Psikodimensia, 14, (1), 97-115.

Satwika, P. A., \& Himam, F. (2014). Kinerja karyawan berdasarkan keterbukaan terhadap pengalaman, organizational citizenship behavior dan budaya organisasi. Jurnal Psikologi, 41, (2), 205-217.

Schaufeli, W. B., Salanova, M., GonzalesRoma, V., \& Bakker, A. B. (2002). The measurement of engagament and burnout: A two sample confirmatory factor analityc approach. Journal of Happines Studies, 3, 71-92.

Schaufeli, W. B., \& Bakker, A. (2003). UWES: Utrecht work engagament scale, premilinary manual. Utrecht University: Occupational Health Psychology Unit.

Schaufeli, W. B., \& Bakker, A. (2004). Job demands, job resources, and their relationship with burnout and engagement: a multi-sample study. Journal of Organizational Behavior, 25, 293-315.

Setiawan, I. A. (2012). Hubungan antara perceived organizational support, job engagement, dan task performance dengan organizational citizenship behavior. Jurnal Sains Manajemen \& Akutansi, IV, (2), 1-14.

Sitepu, A. T. (2013). Beban kerja dan motivasi pengaruhnya terhadap kinerja karyawan pada PT. Bank Tabungan Negara, Tbk Cabang Manado. Jurnal EMBA, 1, (4), 11231133. 
Sugiyono. (2009). Metode penelitian kuantitatif kualitatif dan $R \& D$. Bandung: Alfabeta.

Surahman, R. (2016). Ini cara Bank PT. Bank Rakyat Indonesia (Persero) Tbk tingkatkan kualitas SDM. Diakses pada tanggal 3 Desember 2016 melalui situs: http://www.enciety.co/cara-bank-PT.

Bank Rakyat Indonesia (Persero) Tbk,tingkatkan-kualitas-sdm/.

Suseno, E. S., Hamid, D., \& Ruhana, I. (2014). Pengaruh kompensasi finansial dan non finansial terhadap kinerja karyawan (studi pada Bank Rakyat Indonesia Cabang Jember). Jurnal Administrasi Bisnis, 8, (2), 16.

Susmiati, S., \& Sudarma, K. (2015). Pengaruh budaya organisasi dan dukungan organisasi persepsian terhadap kinerja karyawan dengan komitmen organisasi sebagai variabel intervening. Management Analysis Journal, 4 (1).

Widodo, F. A. S., \& Sami'an. (2013). Hubungan employee engagement dengan perilaku produktif karyawan.
Jurnal Psikologi Industri dan Organisasi, 2 (1), 1-6.

Widjaja, D. C., Fulbertus, M., \& Kusuma, F. (2008). Analisis persepsi employee empowerment terhadap employee turnover intention di Hotel X, Kupang, Nusa Tenggara. Jurnal Manajemen Perhotelan, 4, (2), 72-84.

Wiyanti, S. (2013). Banyak cabang di pelosok bikin orang tertarik kerja di BRI. Diakses pada tanggal 3 Desember 2016 melalui situs: https://www.merdeka.com/uang/bany ak-cabang-di-pelosok-bikin-orangtertarik-kerja-di-bri.html.

Yusrina. (2013). Peranan citra perusahaan terhadap kepercayaan nasabah Bank BRI Cabang Banda Aceh. Jurnal Ekonomi Manajemen dan Bisnis, 1, (2), 203-213.

Zulkarnain., \& Hadiyani, S. (2014). Peranan komitmen organisasi dan employee engagament terhadap kesiapan karyawan untuk berubah. Jurnal Psikologi, 41, (1), 17-33. 